Published in final edited form as:

DNA Repair (Amst). 2007 August 1; 6(8): 1210-1221.

\title{
Live and let die:
}

\section{in vivo selection of gene-modified hematopoietic stem cells via MGMT-mediated chemoprotection}

\author{
Michael D. Milsom ${ }^{1}$ and David A. Williams ${ }^{1,2}$ \\ 1Cincinnati Children's Research Foundation, Cincinnati Children's Hospital Medical Center, Division of \\ Experimental Hematology, 3333 Burnet Avenue, Cincinnati, Ohio 45229, USA.
}

\begin{abstract}
Gene transfer into hematopoietic stem cells (HSC) provides a potential means of correcting monogenic defects and altering drug sensitivity of normal bone marrow to cytotoxic agents. These applications have significant therapeutic potential but the translation of successful murine studies into human therapies has been hindered by low gene transfer in large animals (including humans), and recent serious side effects in a human immunodeficiency trial related to insertional mutagenesis. The latter trial, along with other subsequent trials, while bringing into focus the potential risks of integrating vector systems, also clearly demonstrate the potential usefulness of in vivo selection as it relates to inefficient stem cell transduction. Developing from initial studies by our group and other investigators in which drug resistance was utilized to demonstrate the feasibility of using gene transfer to effect protection from myelotoxicity of chemotherapeutic agents, expression of mutant forms of $O^{6}$-methyguanine-DNA-methytransferase (MGMT) coupled with the simultaneous use of pharmacologic inhibitors and chemotherapeutic agents has been shown to provide a powerful method to select HSC in vivo. While stem and progenitor cell protection and resulting selection in vivo has potential applications for the treatment of selected cancers (allowing dose escalation) andor correction of monogenic disease (allowing an iatrogenic survival advantage of transduced cells in vivo), such an in vivo selection may have untoward effects on stem cell behavior. These deleterious effects may include stem cell exhaustion; lineage skewing; accumulation of genotoxic lesions; and clonal dominance driven towards a pro-leukemic phenotype. Knowledge of the likelihood of such deleterious events occurring as well as their potential implications will be critical to future clinical applications and may also enhance our understanding of both normal stem cell behavior and the evolution of hematopoietic malignancies.
\end{abstract}

\section{Keywords \\ $O^{6}$-methylguanine-DNA-methytransferase; chemoprotection; in vivo selection; chemoselection; gene therapy; hematopoiesis; insertional mutagenesis}

\footnotetext{
${ }^{2}$ To whom correspondence should be addressed: David A. Williams, Director of Division of Experimental Hematology, Cincinnati Children's Hospital Research Foundation, Cincinnati Children's Hospital Medical Center, 3333 Burnet Avenue, Cincinnati, Ohio 45229, USA., Tel: (+1) 513636 0364, Fax: (+1) 513636 8614, E-mail: david.williams@cchmc.org

Publisher's Disclaimer: This is a PDF file of an unedited manuscript that has been accepted for publication. As a service to our customers we are providing this early version of the manuscript. The manuscript will undergo copyediting, typesetting, and review of the resulting proof before it is published in its final citable form. Please note that during the production process errors may be discovered which could affect the content, and all legal disclaimers that apply to the journal pertain.
} 


\section{Introduction}

Hematopoietic stem cells (HSC) represent an important target for gene transfer. Biological characteristics of these cells as relates to their use in gene transfer experiments include a significant proliferative capacity, comprising the capability for self-renewal divisions, and pluripotency. In spite of 22 years of successful use of retrovirus vectors for transduction of murine $\mathrm{HSC}\left[{ }^{1}\right]$, transduction of stem cells from large animals, including humans, has remained problematic $\left[{ }^{2-4}\right]$. Recent advances, such as improved cytokines for minimizing commitment during ex vivo expansion, fibronectin-assisted gene transfer and purification of stem cells using clinical CD34 devices have improved the efficiency of gene transfer into human cells and enhanced human gene therapy trials $[5,6]$. In spite of these improvements, the efficiency of gene transfer into primitive human hematopoietic cells and the engraftment of large numbers of transduced cells in clinical trials remains a major challenge to broaden the application of this technology for the successful treatment of cancer and genetic diseases.

The recent dual success $\left[{ }^{6}\right]$ and serious adverse events $\left[{ }^{7,8}\right]$ in a gene therapy trial in X-linked severe combined immunodeficiency (X-SCID) disease provides evidence of the powerful utility of in vivo selection of transduced cells to favor the repopulation of transduced cells in the blood and marrow. Patients with X-SCID lack the IL-2 receptor common gamma chain $(\gamma \mathrm{C})$ and have severely deficient immune function and lymphocyte numbers. In the X-SCID trial, infusion of CD34+ cells transduced with a vector encoding $\gamma \mathrm{C}$ led to correction of the immune system in the first 9/10 patients treated. Although engraftment of transduced HSC appeared low and the number of gene-marked myeloid cell was similar to previous trials, the patients demonstrated nearly complete repopulation of the immune system with progeny lymphocytes of transduced stem cells. Three patients in this trial have ultimately developed vector insertion-related leukemia. However, the results of this experience strongly suggest that in vivo selection of transduced cells, in this case restricted to a particular hematopoietic lineage, may be a particularly attractive method of enhancing the repopulation of transduced cells in vivo.

Another indicator of the possible therapeutic utility of in vivo selection in achieving a curative level of gene modified cells comes from a second clinical trial in X-linked chronic granulomatous disease (X-CGD) $\left[{ }^{9}\right]$. X-CGD results from a defect in the gene encoding gp91 $1^{\text {phox }}$, a subunit of the nicotinamide dinucleotide phosphate oxidase (NADPH) complex which is required for the oxidative antimicrobial activity of phagocytes. In this trial, two patients were infused with autologous CD34+ cells which had been transduced with a retroviral vector encoding gp9 $1^{\text {phox }}$. Both patients subsequently demonstrated a non-malignant expansion of gene modified cells. Expansion of gene marked cells was apparently driven by the emergence of selected myeloid progenitor clones, contributing an increasing number of gene corrected neutrophils over time. Correction of X-CGD would not be predicted to provide either a survival or proliferation advantage to either the undifferentiated or differentiated myeloid compartments. Instead, transcriptional activation of cellular pro-engraftment genes by the integrated provirus likely led to the emergence of these dominant clones, as previously predicted in a murine model[ $\left[{ }^{10}\right]$. Significantly, after this expansion of gene modified myeloid cells, phagocytic killing was functionally restored and in both patients pre-existing infections were clinically resolved. Hence, despite the concern that this expansion of transduced cells may represent a "pre-leukemic event", this trial provides further evidence of the feasibility of in vivo expansion of transduced human $\mathrm{HSC} /$ progenitors to elicit a therapeutic effect. In this context, the transfer and expression of chemoresistance genes has been suggested as one method to effect in vivo selection in genetic diseases where no selective pressure is exerted on the stem cell or progenitor populations by the disease phenotype $\left.{ }^{4,11-14}\right]$. 


\section{Engineering chemoresistance}

Since dose intensification in many cancer chemotherapy protocols is limited by severe hematopoietic toxicities, generation of hematopoietic stem and progenitor cells resistant to these agents may protect patients from life-threatening blood cytopenias $\left.{ }^{15}\right]$. Several chemoprotective approaches have been evaluated and shown to confer varying degrees of protection to the HSC and progenitor compartment. Ectopic expression of the multidrug resistance gene (MDR1) [ $5,16-19]$; the dihidrofolate reductase (DHFR) gene $\left[{ }^{20-24}\right]$; the cytidine deaminase gene [ $\left.{ }^{25-28}\right]$; and the MGMT gene $\left[{ }^{29-39}\right.$ ]have been extensively investigated as potential chemoprotectants. Since stable gene transfer to the stem cell compartment is desirable for a chemoprotective strategy, efforts have almost exclusively focused on the use of retroviral vectors ( $\gamma$-retroviral and lentiviral) for delivery of the drug resistance genes to primitive hematopoietic cells. Our group and others have evaluated the over-expression of MGMT both in vitro and in vivo since endogenous levels of MGMT in the bone marrow are extremely low and because myelosuppression is a major dose limiting toxicity of several drugs effecting DNA adducts which are resolved by this repair protein, such as $O^{6}$ methylating and chloroethylating agents $\left[{ }^{4,15,40}\right]$.

A variety of tumors evade chemosensitivity towards these agents by induced expression of MGMT. MGMT repairs DNA damage mediated by chloroethylating and methylating agents by removing adducts from the $O^{6}$ position of guanine $\left[{ }^{34,41-43}\right.$ ]. If these adducts remain unresolved by MGMT then the resulting DNA interstrand crosslinks or futile cycles of the mismatch repair pathway are able to trigger the apoptotic machinery[ $\left.{ }^{44}\right]$. Over-expression of wild type MGMT in the bone marrow may not be sufficient to protect hematopoietic cells from high dose chemotherapy required to treat resistant tumors which have induced markedly increased levels of MGMT activity. In vitro and xenograft studies have shown significant sensitization of a variety of tumors to alkylating agents by MGMT depletion with the nucleotide $O^{6}$-benzylguanine (6-BG) and other pseudosubstrate inhibitors[ $\left.{ }^{45-49}\right]$. 6-BG is a base analogue which irreversibly inactivates MGMT. The major limitation of the use of 6-BG in pre-clinical models and in human trials has been severe, dose-related bone marrow toxicity, likely due to further depletion of low endogenous MGMT levels in hematopoietic cells $\left[{ }^{50-57}\right]$. Our group and others have evaluated the efficacy of chemoprotection using mutant forms of MGMT that are highly resistant to pseudosubstrate-mediated depletion and retain repair activity $[31,33,35,37,58-63]$. Thus, this combined genetic and pharmacologic approach allows sensitization of tumors to alkylating agents and simultaneous reduction in bone marrow toxicity $[4,13,40]$.

In addition to potential use in generating chemoresistance, we and others have found that the combined use of 6-BG and MGMT mutants leads to effective in vivo selection of transduced stem cells, including human HSC in xenograft models [35,37,62,64]. This approach could have additional therapeutic applications in genetic diseases, as demonstrated in mouse models of thalassemia[ $\left.{ }^{65}\right]$; protoporphyria[ $\left.{ }^{66}\right]$; HIV therapy $\left[{ }^{67,68}\right.$; and graft modulation following allogeneic transplant. Importantly, it has recently been demonstrated that the effective chemoresistance and in vivo selection seen in murine models can be robustly recapitulated in large animal canine allograft and autograft models $\left[{ }^{39,62}\right]$. To date however, in two reported clinical trials of MGMT gene delivery for chemoprotection in patients with advanced malignancies, there is no evidence of selection at the stem cell level in humans $\left[{ }^{69,70}\right]$. This is likely due to low efficiencies of stem cell transduction, probably as a result of low viral titers in clinical grade vector products. An additional difficulty in interpreting these clinical trial data is the lack of long-term follow up after multiple rounds of chemotherapy administration due to patients succumbing to progressive disease. Nonetheless, in both trials, retroviral transduction was observed in hematopoietic progenitors and no adverse effects attributed to the gene transfer protocol were observed. 
As an aside to the topic of engineering MGMT-mediated chemoselection to expand transduced cells for correction of a monogenic disease, it is pertinent to raise the technical issue of the optimal way to co-express both the drug resistance gene and the therapeutic cDNA. The various mechanisms available for co-expressing MGMT with a second gene in the same cell (dual promoters; fusion genes; alternate splicing; internal ribosome entry site; self processing esterase; post-translational cleavage; and co-transduction with more than one vector) have been discussed elsewhere $\left.{ }^{40,71,72}\right]$ and are beyond the scope of this article. However, it should be noted that the choice of method for co-expression will have a significant impact on the level of expression of the corrective gene as well as the amount of biologically active MGMT, the ramifications of which will be discussed later in this review.

\section{Chemoselection and stem cell biology}

The genetic modification of human HSC is particularly attractive since transduced HSC should persist for the lifetime of the individual and generate progeny which comprise all the mature hematopoietic lineages $\left[{ }^{73}\right]$. In theory, the proliferative capacity of an individual gene-modified HSC is extremely high. While this proliferative capacity and longevity is the key to successful therapeutic application, it is also the source of one of the major risk factors associated with this approach. Thus, any genotoxic damage to HSC has the potential to persist through many generations of progeny, hypothetically a scenario which could drive the evolution of hematological malignancies.

The alkyl lesion at the $O^{6}$ position of guanine is considered the major toxic DNA adduct produced by $O^{6}$ methylating and chloroethylating agents such as temozolomide (TMZ) and 1,3-bis(2-chloroethy)-1-nitrosourea (BCNU) $\left.{ }^{74-78}\right]$. In addition to $O^{6}$-alkylguanine lesions leading to cell death via apoptosis (following futile cycles of the mismatch repair pathway or interstrand crosslinks), these adducts are also mutagenic; clastogenic; and carcinogenic [ ${ }^{44}$, 79,80 ]. Hence, the frequency of adduct removal, which is directly related to the expression level of MGMT within a particular cell, is critical not only for cell survival but also for the reduction of potentially transforming genotoxic damage $\left[{ }^{81}\right]$. Indeed, it is possible that some stem cells may accumulate too few adducts to engage the programmed cell death pathway. These cells might then survive while harboring mutagenic lesions. In practice, there is little evidence that such a chemoprotective strategy would promote leukemia in cells which overexpress MGMT. In fact, gene modified hematopoietic cells demonstrate a significant reduction in mutation frequency and chromosomal aberrations upon challenge with $O^{6}$ alkylating agents $\left[{ }^{31,82-84}\right]$ and mice transgenic for human MGMT show a decrease in cellular transformation frequency upon drug treatment $\left[{ }^{85-89}\right]$. Perhaps most compelling in this regard is the observation that there was no evidence of hematopoietic malignancy following an extended, dose escalating chemotherapeutic regimen in a canine large animal model which enabled selection of gene modified cells $\left[{ }^{62}\right]$. Nevertheless, it is pertinent to consider whether alternative chemotherapeutic regimens (e.g. acute high dose model for chemoprotection versus gradual dose escalation over a longer period of time for chemoselection) or variable expression of the MGMT cDNA in the stem cell compartment (as might be expected with different vector promoters or lower HSC transduction rates in humans compared to murine models) could contribute towards a greater probability of mutagenesis/transformation.

Even if the likelihood of significant genotoxic damage is reduced in HSC transduced with an MGMT expressing vector, the question remains whether non-gene modified HSC will accumulate transforming mutations. Again, this may well depend on the chemotherapeutic regimen since it may be possible to purge virtually all the non-transduced HSC with a stringent treatment protocol. The literature would indicate that this is indeed the case, as MGMT chemoselective regimens are frequently reported to dramatically increase the chimerism of gene modified cells in murine models, with few associated secondary malignancies[35,37, 
$38,42,65,90]$. However, the chemotherapeutic regimens employed to achieve such in vivo selection can be harsh and result in non-hematopoietic therapy-associated side effects. This raises the issue of whether such striking enrichment of gene modified cells can be achieved in humans with acceptable rates of toxicity. Certainly, the large animal canine study of MGMT chemoselection demonstrates that with an appropriate drug schedule it is indeed possible to achieve a clinically relevant degree of in vivo selection while not apparently jeopardizing the animal[ $\left.{ }^{62}\right]$. Notably in this study, the use of 6-BG in concert with TMZ caused no significant collateral toxicity in extra-hematopoietic tissues. This observation correlates with results obtained in clinical trials[ $\left.{ }^{91,92}\right]$.

Although the $O^{6}$-methylguanine lesion is the most toxic, other DNA alkyl adducts are formed as a result of treatment with $O^{6}$ alkylating agents. These include: $\mathrm{N}^{3}$ of adenine; $\mathrm{N}^{7}$ of guanine; $O^{2}$ of thymine and $O^{4}$ of thymine. These lesions in fact make up the majority of DNA adducts caused by $O^{6}$ alkylating agents $\left[{ }^{44}\right]$. The potential to induce mutations, genetic instability and a malignant phenotype has been described for some of these adducts in cell lines and rodent tissues[ $\left.{ }^{93-95}\right]$. However, the potential role of these lesions in HSC fate is unknown. Thus, these lesions may play a significant role in the long-term sequelae of therapy with $O^{6}$ alkylators and this could be of particular relevance in cells protected from acute toxicities of $O^{6}$ lesions by overexpression of MGMT. In this setting it seems likely (but yet unproven) that cells which survive increased doses of alkylating agents due to enhanced repair of the $O^{6}$-methylguanine lesion, will accrue elevated non- $O^{6}$-guanine alkylation-induced lesions. Thus, the fate (persistence versus repair) of these lesions in relation to their genotoxic effects (strand breaks; genetic instability and point mutations) in gene modified HSC would seem to be an area which would warrant future investigation.

In addition to the direct damage of DNA, cells are also likely to suffer increased alkylation of other cellular components (e.g. other macromolecules such as lipids and proteins). It is not known whether the chemotherapeutic alkylation of molecules other than DNA has any effect upon HSC biology. Dose escalation facilitated by chemoprotection/selection will almost certainly increase the frequency of these pan-cellular alkylation events and may have consequences in terms of viability, proliferation capacity, differentiation, quiescence and senescence.

\section{Vector induced insertional mutagenesis and clonal selection}

As noted above, an additional toxicity which has been brought to attention by the X-SCID trial is insertional mutagenesis (reviewed in $\left[{ }^{96-101}\right]$ ). With a latency period of three years after infusion of gene-modified cells, three successfully treated patients in the French X-SCID trial developed T cell leukemia $\left[{ }^{7,8}\right]$. Importantly, abnormal expression of a known proto-oncogene, LMO2, was shown in two of these patients to be associated with transgene insertion in this locus. In the third patient, the leukemic clone also harbored a proviral integrant in the vicinity of LMO2. Previous studies in a variety of species have predicted insertional oncogenesis as a potential but remote risk of gene transfer using retrovirus vectors $[96,102]$. Thus the high frequency of evolution of insertion-related leukemogenesis and the long latency period observed both suggest that a strong expansion pressure on transduced cells in vivo may play a role in the evolution of this disease. Indeed, the process of serially transplanting HSC (an approach that places a severe proliferative stress on HSC as the cells reconstitute successive recipients) has been reported to significantly increase the frequency of leukemia development unrelated to vector insertion (G. Wagermaker, Erasmus University Rotterdam, personal communication). This correlates with studies using gene modified HSC where secondary transplant appears to have unmasked the emergence of either leukemic clones (at a high vector copy number) [ $\left.{ }^{103,104}\right]$ or dominant non-malignant clones (at a low vector copy number) [10]. 
All gene transfer methods that lead to integration of DNA into the chromosome carry a risk of mutagenesis. The integration of retroviruses, including lentiviruses and spumaviruses, could lead to inactivation of tumor suppressor genes; deregulated expression of a gene with no significant consequences; or activation of a proto-oncogene. The former are likely to be of less clinical relevance, since loss of heterozygosity would be required for phenotypic consequences $\left[{ }^{105}\right]$. The latter is a potential greater risk, since it requires only dominant monoallelic activation of a gene within the vicinity of the insertion. Physical and biological properties of the target DNA and the retrovirus life cycle appear to generate a preference for insertion in the vicinity of active genes. It appears that vectors based on lentiviruses and spumaviruses demonstrate slightly altered insertion profiles to $\gamma$-retroviruses [ $\left.{ }^{106-111}\right]$. For instance, HIV-1 appears to integrate within the coding region of genes more frequently than $\gamma$-retroviruses which demonstrate a preference for the $5^{\prime}$ end of genes in the vicinity of enhancer/promoter regions. However, the biological relevance of these differences, identified in experimental systems, is unknown. Thus, it is unclear whether this altered insertion profile of lentivirusbased vectors corresponds to an actual difference in the potential transformation properties of these vector systems [ $\left.{ }^{112}\right]$, or whether perceived differences in mutagenic potential could be explained by elements of vector architecture $\left.{ }^{113}\right]$. Enhancer elements present within retroviral vectors may activate cellular genes over large distances ( $>10$ kilobases). If we consider the presence of $>100$ proto-oncogenes within the human genome, then it is feasible that oncogene deregulations may occur in the order of 0.1 to $1 \%$ of all retroviral gene transfer events. Thus, patients in multiple clinical trials may have been infused with cells carrying retrovirus vectorinsertions near oncogenes while remaining healthy over prolonged periods of observations. These data suggest that in addition to the vector integration near LMO2, other factors may have been critical in the development of clonal disease. One such factor under intense investigation is the possible in vivo expansion of gene modified cells driven by a survival advantage or unregulated expression of the transgene (IL2 common $\gamma$-chain receptor, which initiates an antiapoptotic signaling pathway) $\left[{ }^{114-116}\right]$. It is interesting to note that a similar X-SCID trial has not, at this time, had any incidences of therapy-related leukemia [ $\left.{ }^{117}\right]$. This may have been due to slight differences in the clinical protocol (e.g. culture media; vector pseudotype; relative cell dose) promoting a different biological outcome in the engrafting cells, as exemplified by the slower rate of $\mathrm{T}$ cell reconstitution by gene modified cells in the second trial. Furthermore, in the X-CGD trial described previously, proviral integration at the locus of an oncogene (MDSEVI1) has not yet resulted in the transformation of transduced cells, but only non-malignant expansion $\left[{ }^{9}\right]$. Hence oncogene activation alone apparently is not sufficient to drive leukemogenesis.

With regard to chemoprotection and selection, one important question to be determined is whether insertional mutagenesis will act coordinately with MGMT chemoselection to drive malignant transformation? Theoretically, a chemoselective strategy comprises a setting where transduced cells would undergo a proliferative stress akin to serial transplantation, as limited numbers of HSC are forced to reconstitute the hematopoietic system following chemotherapeutic ablation. Also, because of the stoichiometric nature of $O^{6}$-methylguanine detoxification by MGMT (i.e. one MGMT molecule removing one alkyl adduct), one could envisage that chemoselection would result in the enrichment of HSC clones harboring more than one copy of the MGMT containing provirus which express higher levels of MGMT. Thus, selective pressure could drive expansion of clones that have elevated numbers of insertion sites and therefore an increased frequency of oncogene activation by vector promoter/enhancer elements. In addition, it is conceivable that the mutagenic alkyl adducts described above could act as secondary hits to compliment a pro-leukemic retroviral vector insertion. Finally, many applications of MGMT mediated in vivo selection relate to treatment of disorders seen in infants. Hence, transduced cells may be expected to persist for the lifetime of the individual providing a large window of time to generate "spontaneous" second leukemogenic hits. 
To date, these concerns remain as largely theoretical considerations, with little experimental evidence to support them. In murine studies, multiple groups have demonstrated that MGMT transduced HSC are able to reconstitute secondary recipients after a chemoselective regimen has been applied $[35,37,38,60,65,118]$. No instances of abnormal hematopoiesis or increased rates of hematological malignancy have been reported. Although a comprehensive study on the ability of MGMT mediated chemoselection to impel the emergence of dominant transduced clones has yet to be published, studies in the canine model indicate that selection is polyclonal $\left[{ }^{39,62}\right]$. A possible critique is that in many chemoselective models, the number of input transduced HSC has been low (or has been severely competed against non-transduced cells), therefore the pool of possible advantageous integration site hits has been small. However, in light of the adverse events in the X-SCID trial, this is also perceived as one of the major strengths of the chemoselective approach, i.e. that reduced numbers of transduced HSC (and therefore fewer potentially deleterious integration sites) can be infused into a patient and modulated in vivo by chemoselection to increase the level of chimerism attributed to donortransduced cells. Nonetheless, the relative risk of generating leukemic clones by infusing larger cell numbers versus dramatic in vivo expansion of a small pool of $\mathrm{HSC}$ has not been addressed to date.

Zielske et al. have examined the issue of MGMT mediated in vivo selection leading to enrichment of clones containing multiple vector copies $\left[{ }^{119}\right]$. They describe the predicted rise in MGMT activity with an increasing copy number of MGMT vector in K562 cells. Following treatment with 6-BG and $\mathrm{BCNU}$ in vitro, there was no increase in the average copy number of the culture despite demonstrating selection. While this result is encouraging, it must be stressed that such studies need to be performed in primary HSC, as they are more likely to have a lower threshold for tolerance of genotoxic damage and hence, may respond differently.

Because of the limited life span of mice, it has not been possible to predict the effect of MGMT mediated in vivo selection on normal hematopoiesis/leukemogenesis over longer periods of time (unless one considers serially transplanted transduced murine BMC). The canine model of MGMT chemoselection may be more predictive of the outcome of such a strategy in human HSC. Although only a limited number of animals have been used in such studies, normal hematopoiesis has been reported in selected transduced canine cells with a 3 years period of follow up analysis $\left[{ }^{14,62}\right]$. Hence, there is still no documented evidence of an MGMT in vivo chemoselective strategy driving the evolution of leukemia. However, there is one recent report which describes the occurrence of acute myeloid leukemia in a primate model of chemoselection using a different transgene $\left[{ }^{120}\right]$. In this instance, HSC from a rhesus macaque were transduced with DHFR and, following autologous transplant, was subjected to chemotherapeutic challenge using an antifolate regimen. At five years post-transplant (three years post-selection) a leukemic clone emerged which contained two proviral insertions, one of which was in the proximity of the anti-apoptotic gene BCL2-A1. It is difficult to determine whether the chemoselective regimen played any role in the emergence of this leukemic clone as there are other confounding variables in this study. Amongst these was the unexplained transient, non-malignant expansion of the eventual leukemic clone during the first year after transplant. Nonetheless, this study advocates a potential advantage of using large animal models to investigate potential toxicities associated with chemoselective regimens that may only become apparent following extended observation.

\section{Stem cell exhaustion}

An alternate undesirable outcome of chemoselection could be the eventual failure of the genemodified graft. Previous work examining the effects of various chemotherapeutic agents suggested that $\mathrm{BCNU}$ is toxic to primitive $\mathrm{HSC}\left[{ }^{121}\right]$. Sawai et al. have shown that the combination of 6-BG and TMZ causes severe attrition in the HSC compartment $\left[{ }^{122}\right]$. This 
correlates with a majority of data from MGMT chemoselection on mice using pseudosubstrate inhibitors plus $O^{6}$ alkylating agents, which show that this is one of the most stringent strategies for achieving stable in vivo selection of hematopoietic cells $\left[{ }^{42}\right]$. Therefore by inference, these protocols must rigorously deplete non-protected HSC. As discussed above, such a dramatic depletion of unprotected hematopoiesis would result in a significant proliferative stress being applied to gene-modified HSC as these cells are required to repopulate the hematopoietic system of the treated individual. It is feasible that this would promote the extinction of gene modified hematopoiesis through HSC exhaustion.

In mice, there is little evidence to support the notion that chemoselection promotes HSC failure, as serial transplantation reveals that selected cells are still able to establish multi-lineage engraftment in irradiated recipient mice (see above). One might again argue that HSC exhaustion may only become apparent over a prolonged period of observation. It is not clear that such studies have been rigorously performed to date. In addition, murine HSC may have a different absolute proliferative potential compared with human HSC because of differing biological characteristics e.g. the large telomere length of murine HSC relative to human cells. One approach to examine the premature exhaustion of transduced HSC in the murine model might be by serial transplantation after chemoselection, with a short period of recovery between transplants. However, such an approach would demand additional biological features of the transduced HSC (e.g. ability to survive in vitro manipulation; repetitively home to HSC niche including accomplishing trans-endothelial migration) which may not be necessary to reflect features of steady state hematopoiesis in a non-serial transplant setting over a protracted period post-chemotherapy.

In canine studies, there is little evidence for exhaustion of transduced HSC post-selection. Stable levels of selection have been observed over relatively long periods of time (3 years) with no report of lineage skewing $\left.{ }^{14,62}\right]$. Molecular analysis has shown no dramatic loss of transduced clones with time. The cost of such large animal studies hinders large cohort sizes and the lack of inbred syngeneic strains limits the possibility of serial transplantation. However, these studies represent the best model to date of the behavior of selected transduced HSC observed over a clinically relevant time period.

Despite the proof of principle of MGMT-mediated chemoselection in a large animal model, a note of caution has been raised by a series of experiments using human CD34+ cells in the NOD-SCID xenotransplant system [ $\left.{ }^{64,123}\right]$. While these, and an additional study $\left[{ }^{124}\right]$ clearly show that MGMT transduced human CD34+ cells can be enriched using chemoselection, a high dose 6-BG/BCNU regimen appeared to result in a loss of transduced primitive human cells $\left.{ }^{123}\right]$. While this study suffers from the potential issue of the adequacy of the murine hematopoietic microenvironment to support in vivo expansion of human cells, this finding could be indicative of stem cell exhaustion. The analysis in this study is further complicated by a design that includes the presence of "competing" transduced and drug-resistant murine HSC. Nonetheless, this work clearly highlights the need to define whether selective regimens may place a proliferative stress on transduced HSC.

One possible avenue that may be explored to reduce the likelihood of transduced HSC exhaustion following a chemotherapeutic regimen is to provide a means to enhance the proliferative potential of these cells. An example of how this may be achieved comes through the co-ordinate expression of a drug resistance gene and the homeobox transcription factor HOXB4, which has previously been shown to facilitate the in vitro and in vivo expansion of normal HSC. Retroviral co-expression of HOXB4 along with either DHFR [ ${ }^{122}$ ] or MGMT $\left.{ }^{12}\right]$ has been demonstrated to dramatically improve the recovery of transduced cells following challenge with either an anti-folate or $O^{6}$ alkylator regimen, respectively. However, an 
effective method of applying such a pro-proliferative strategy which minimizes the potential that expanded cells will become transformed has yet to be devised.

\section{Using a sledgehammer to crack a nut?}

Until relatively recently, the effective transduction of HSC with retroviral vectors has been difficult to attain. Hence, researchers have often employed powerful enhancer/promoter units (mostly of viral origin) in retroviral vectors to ensure adequate expression of the transgene payload in transduced cells. At first glance, this approach would still appear to be appropriate for the overexpression of MGMT since the absolute level of protein in a cell will govern the number of alkyl lesions which can be successfully detoxified. Indeed, as discussed previously, a high level MGMT expression may be essential to ensure a low frequency of residual $O^{6}$-alkyl adducts following selection. However, it is possible that vectors which mediate excessive overexpression of MGMT may elicit unwanted side effects in HSC. The issue of overexpression of MGMT potentially resulting in deleterious effects is raised by two general premises: (i) the powerful promoter/enhancer elements required for high trans-gene expression have an increased propensity to cause insertional activation of nearby genes [ $\left.{ }^{101}\right]$; and (ii) the excess cellular level of MGMT may itself have a detrimental effect on HSC.

Viral enhancer/promoters such as the moloney murine leukemia and the spleen focus forming virus have been shown to be associated with insertional leukemogenesis when incorporated into recombinant retroviral vectors $[7,103]$. A current area of research is the optimization of retroviral vector architecture in order to reduce the mutagenic potential of the integrated provirus (reviewed in $\left.{ }^{101,125}\right]$. Efforts have focused on altering the vector composition to minimize the effect of vector promoter/enhancers on the genomic locus adjacent to the integration site. These modified vectors include the use of insulator elements or internal promoters coupled with self-inactivating long terminal repeats (LTRs). A second approach is to use less powerful cellular promoters that may also reduce the risk of transactivating neighboring genes. For example, a recent study has compared cellular promoters to determine if the expression of MGMT can be achieved at a level adequate to afford chemoprotection and selection in vitro $\left.{ }^{126}\right]$. Although these promoters performed adequately in cell lines, this was not the case when primary murine derived colony forming cells were examined. Therefore a balance may need to be obtained between expressing MGMT at a level adequate for protection while minimizing trans-activation potential. A study by Kaina and colleagues demonstrates that in stable transfected cell lines, at a high level of MGMT expression, there is little additional chemoprotective effect to further elevating the expression level of ectopic MGMT $\left[{ }^{127}\right]$. It would thus appear that this mechanism of protection may plateau at a certain level of MGMT overexpression which will be important to define in future studies. Additionally, it is likely that these optimization experiments would best be performed in vivo to obtain clinically meaningful results and to define a therapeutic window for MGMT expression in an HSC based chemoselective strategy. Certainly, if required, vector architecture can be further improved to enable higher expression of MGMT with these same cellular promoters (e.g. by enhancing post-transcriptional processing; increasing mRNA stability or codon optimization of the cDNA). An alternative approach is to develop vectors in which MGMT is expressed via inducible promoters.

A potentially more problematic issue to overcome would be if overexpression of MGMT itself has a detrimental effect on HSC biology. There is a limited amount of preliminary data which suggests that MGMT overexpression may restrict the proliferation of hematopoietic cell lines in a dose dependent manner $\left.{ }^{128}\right]$ and perturb the engraftment of $\left.\mathrm{HSC}^{12}\right]$ (T. Moritz, University of Duisburg/Essen Medical School, personal communication). It is difficult to envisage a mechanism which would explain these effects. Notwithstanding this, any 
detrimental effect of overexpression of MGMT appears not to restrict the ability of transduced HSC to expand following chemoselection.

\section{Conclusions}

The use of MGMT-mediated chemoprotection in order to selectively expand gene modified HSC in vivo holds significant promise for translation into the clinic. Furthermore, the combined pharmacologic and genetic approach utilizing mutants of MGMT is a powerful strategy to modulate the chimerism of transduced HSC and has been clearly demonstrated to be effective across a number of different model systems. In this review, areas of future work which would refine an already effective approach have been highlighted. In this era of heightened concern over the safety of using integrating vector systems to deliver genes into HSC, it is important to consider the risk versus benefit of this system from a therapeutic standpoint taking into account the specific disease to be approached (Figure 1). Most of the ongoing and proposed phase I clinical trials using MGMT overexpression to protect HSC against the toxicity of $O^{6}$ alkylating agents have focused on the treatment of patients who have high grade malignancies which are either refractory to conventional therapy or prognostically are likely not to respond to such therapy. In this regard, many chemotherapeutic agents that are currently in clinical use are themselves potent mutagens that have been shown to promote cellular transformation. Thus, future basic studies will seek to enhance the safety of vectors while translational and clinical trials will contribute new information regarding the most appropriate applications of gene therapy technology in human disease.

\section{Acknowledgements}

The authors wish to thank Geoff Margison (Paterson Institute for Cancer Research, Manchester, UK) and Tom Moritz (University of Essen, Essen, Germany) for critical review of this manuscript, and Jürgen Thomale (University of Essen, Essen, Germany) for helpful discussions.

\section{References}

[1]. Williams DA, Lemischka IR, Nathan DG, Mulligan RC. Introduction of new genetic material into pluripotent haematopoietic stem cells of the mouse. Nature 1984;310:476-480. [PubMed: 6087158]

[2]. Dunbar CE, Cottler-Fox M, O’Shaughnessy JA, Doren S, Carter C, Berenson R, Brown S, Moen RC, Greenblatt J, Stewart FM, Leitman SF, Wilson WH, Cowan K, Young NS, Nienhuis AW. Retrovirally marked CD34-enriched peripheral blood and bone marrow cells contribute to longterm engraftment after autologous transplantation. Blood 1995;85:3048-3057. [PubMed: 7538814]

[3]. Brenner MK, Rill DR, Moen RC, Krance RA, Mirro JJ, Anderson WF, Ihle JN. Gene-marking to trace origin of relapse after autologous bone-marrow transplantation. Lancet 1993;341:85-86. [PubMed: 8093407]

[4]. Moritz, T.; Williams, DA. Encyclopedia of Cancer. 2002. Transfer of Drug Resistance Genes to Hematopoietic Precursors; p. 433-447.

[5]. Abonour R, Williams DA, Einhorn L, Kato I, Ward M, William SD, Hromas R, Smith F, Woo D, Mills B, Srour EF, Cornetta K. Efficient retrovirus-mediated transfer of the multidrug resistance 1 gene into autologous human long-term repopulating hematopoietic stem cells. Nat Med 2000;6:652-658. [PubMed: 10835681]

[6]. Cavazzana-Calvo M, Hacein-Bey S, de Saint Basile G, Gross F, Yvon E, Nusbaum P, Selz F, Hue C, Certain S, Casanova JL, Bousso P, Deist FL, Fischer A. Gene therapy of human severe combined immunodeficiency (SCID)-X1 disease [see comments]. Science 2000;288:669-672. [PubMed: 10784449]

[7]. Hacein-Bey-Abina S, Von Kalle C, Schmidt M, McCormack MP, Wulffraat N, Leboulch P, Lim A, Osborne CS, Pawliuk R, Morillon E, Sorensen R, Forster A, Fraser P, Cohen JI, de Saint Basile G, Alexander I, Wintergerst U, Frebourg T, Aurias A, Stoppa-Lyonnet D, Romana S, Radford-Weiss I, Gross F, Valensi F, Delabesse E, Macintyre E, Sigaux F, Soulier J, Leiva LE, Wissler M, Prinz C, Rabbitts TH, Le Deist F, Fischer A, Cavazzana-Calvo M. LMO2-associated clonal T cell 
proliferation in two patients after gene therapy for SCID-X1. Science 2003;302:415-419. [PubMed: 14564000]

[8]. Hacein-Bey-Abina S, Schmidt M, Le Deist F, Garrigue A, Borkhardt A, Wulffraat N, Alexander IE, Wintergerst U, Leiva L, Delabesse E, MacIntyre E, Gougeon ML, Gyapay G, Weinssenbach J, Fraser CC, de Saint Basile G, Casanova JL, Von Kalle C, Fischer A, Cavazzana-Calvo M. Gene therapy for severe combined immunodeficiency X1. Blood 2005;106:60a.

[9]. Ott MG, Schmidt M, Schwarzwaelder K, Stein S, Siler U, Koehl U, Glimm H, Kuhlcke K, Schilz A, Kunkel H, Naundorf S, Brinkmann A, Deichmann A, Fischer M, Ball C, Pilz I, Dunbar C, Du Y, Jenkins NA, Copeland NG, Luthi U, Hassan M, Thrasher AJ, Hoelzer D, von Kalle C, Seger R, Grez M. Correction of X-linked chronic granulomatous disease by gene therapy, augmented by insertional activation of MDS1-EVI1, PRDM16 or SETBP1. Nat Med 2006;12:401-409. [PubMed: 16582916]

[10]. Kustikova O, Fehse B, Modlich U, Yang M, Dullmann J, Kamino K, von Neuhoff N, Schlegelberger $\mathrm{B}$, Li Z, Baum C. Clonal dominance of hematopoietic stem cells triggered by retroviral gene marking. Science 2005;308:1171-1174. [PubMed: 15905401]

[11]. Sorrentino BP. Gene therapy to protect haematopoietic cells from cytotoxic cancer drugs. Nat Rev Cancer 2002;2:431-441. [PubMed: 12189385]

[12]. Milsom MD, Woolford LB, Margison GP, Humphries RK, Fairbairn LJ. Enhanced In Vivo Selection of Bone Marrow Cells by Retroviral-Mediated Co-exprssion of Mutant O6-Methylguanine-DNAMethytransferase and HOXB4. Molecular Therapy 2004;10:862-873. [PubMed: 15509504]

[13]. Bank A. Hematopoietic stem cell gene therapy: selecting only the best. J Clin Invest 2003;112:14781480. [PubMed: 14617747]

[14]. Neff T, Beard BC, Kiem HP. Survival of the fittest: in vivo selection and stem cell gene therapy. Blood 2006;107:1751-1760. [PubMed: 16269617]

[15]. Gerson SL. Clinical relevance of MGMT in the treatment of cancer. J Clin Oncol 2002;20:23882399. [PubMed: 11981013]

[16]. Hanania EG, Fu S, Zu Z, Hegewisch-Becker S, Korbling M, Hester J, Durett A, Andreeff M, Mechetner E, Holzmayer T, et al. Chemotherapy resistance to taxol in clonogenic progenitor cells following transduction of CD34 selected marrow and peripheral blood cells with a retrovirus that contains the MDR-1 chemotherapy resistance gene [see comments]. Gene Ther 1995;2:285-294. [PubMed: 7552989]

[17]. Hesdorffer C, Ayello J, Ward M, Kaubisch A, Vahdat L, Balmaceda C, Garrett T, Fetell M, Reiss R, Bank A, Antman K. Phase I trial of retroviral-mediated transfer of the human MDR1 gene as marrow chemoprotection in patients undergoing high-dose chemotherapy and autologous stem-cell transplantation. Journal of Clinical Oncology 1998;16:165-172. [PubMed: 9440739]

[18]. Hildinger M, Eckert HG, Schilz AJ, John J, Ostertag W, Baum C. FMEV vectors: both retroviral long terminal repeat and leader are important for high expression in transduced hematopoietic cells. Gene Ther 1998;5:1575-1579. [PubMed: 9930313]

[19]. Schiedlmeier B, Kühlcke K, Eckert HG, Baum C, Zeller WJ, Fruehauf S. Quantitative assessment of retroviral transfer of the human multidrug resistance 1 gene to mobilized peripheral blood progenitor cells engrafted in nonobese diabetic/severe combined immunodeficient mice. Blood 2000;95:1237-1248. [PubMed: 10666196]

[20]. Williams DA, Hsieh K, DeSilva A, Mulligan RC. Protection of bone marrow transplant recipients from lethal doses of methotrexate by the generation of methotrexate-resistant bone marrow. J Exp Med 1987;166:210-218. [PubMed: 3298524]

[21]. Corey CA, DeSilva A, Holland C, Williams DA. Serial transplantation of methotrexate-resistant bone marrow: Protection of murine recipients from drug toxicity by progeny of transduced stem cells. Blood 1990;75:337-343. [PubMed: 1967217]

[22]. Warlick CA, Diers MD, Wagner JE, McIvor RS. In vivo selection of antifolate-resistant transgenic hematopoietic stem cells in a murine bone marrow transplant model. J Pharmacol Exp Ther 2002;300:50-56. [PubMed: 11752096]

[23]. Allay JA, Persons DA, Galipeau J, Riberdy JM, Ashmun RA, Blakley RL, Sorrentino BP. In vivo selection of retrovirally transduced hematopoietic stem cells. Nature Medicine 1998;4:1136-1143. 
[24]. Persons DA, Allay JA, Bonifacino A, Lu T, Agricola B, Metzger ME, Donahue RE, Dunbar CE, Sorrentino BP. Transient in vivo selection of transduced peripheral blood cells using antifolate drug selection in rhesus macaques that received transplants with hematopoietic stem cells expressing dihydrofolate reductase vectors. Blood 2004;103:796-803. [PubMed: 12920024]

[25]. Eliopoulos N, Al-Khaldi A, Beausejour CM, Momparler RL, Momparler LF, Galipeau J. Human cytidine deaminase as an ex vivo drug selectable marker in gene-modified primary bone marrow stromal cells. Gene Ther 2002;9:452-462. [PubMed: 11938460]

[26]. Beausejour CM, Eliopoulos N, Momparler L, Le NL, Momparler RL. Selection of drug-resistant transduced cells with cytosine nucleoside analogs using the human cytidine deaminase gene. Cancer Gene Ther 2001;8:669-676. [PubMed: 11593336]

[27]. Momparler RL, Eliopoulos N, Bovenzi V, Letourneau S, Greenbaum M, Cournoyer D. Resistance to cytosine arabinoside by retrovirally mediated gene transfer of human cytidine deaminase into murine fibroblast and hematopoietic cells. Cancer Gene Ther 1996;3:331-338. [PubMed: 8894252]

[28]. Rattmann I, Kleff V, Sorg UR, Bardenheuer W, Brueckner A, Hilger RA, Opalka B, Seeber S, Flasshove M, Moritz T. Gene transfer of cytidine deaminase protects myelopoiesis from cytidine analogs in an in vivo murine transplant model. Blood. 2006

[29]. Moritz T, Mackay W, Glassner BJ, Williams DA, Samson L. Retrovirus-mediated expression of a DNA repair protein in bone marrow protects hematopoietic cells from nitrosourea-induced toxicity in vitro and in vivo. Cancer Res 1995;55:2608-2614. [PubMed: 7780976]

[30]. Maze R, Kapur R, Williams D. Genetically modified hematopoietic stem cells expressing O6methylguanine DNA methyltransferase via a retrovirus vector protect the lymphoid and stem cell compartments in long-term engrafted animals treated with nitrosourea. J Invest Med 1996;44:318A.

[31]. Chinnasamy N, Rafferty JA, Hickson I, Lashford LS, Longhurst SJ, Thatcher N, Margison GP, Dexter TM, Fairbairn LJ. Chemoprotective gene transfer II: multilineage in vivo protection of haemopoiesis against the effects of an antitumour agent by expression of a mutant human O6alkylguanine-DNA alkyltransferase. Gene Ther 1998;5:842-847. [PubMed: 9747465]

[32]. Hickson I, Fairbairn LJ, Chinnasamy N, Lashford LS, Thatcher N, Margison GP, Dexter TM, Rafferty JA. Chemoprotective gene transfer I: transduction of human haemopoietic progenitors with O6-benzylguanine-resistant O6-alkylguanine-DNA alkyltransferase attenuates the toxic effects of O6-alkylating agents in vitro. Gene Ther 1998;5:835-841. [PubMed: 9747464]

[33]. Davis BM, Koc ON, Gerson SL. Limiting numbers of G156A O(6)-methylguanine-DNA methyltransferase-transduced marrow progenitors repopulate nonmyeloablated mice after drug selection. Blood 2000;95:3078-3084. [PubMed: 10807772]

[34]. Davis BM, Koc ON, Reese JS, Gerson SL. O6-benzylguanine-resistant mutant MGMT genes improve hematopoietic cell tolerance to alkylating agents. Prog Exp Tumor Res 1999;36:65-81. [PubMed: 10386065]

[35]. Ragg S, Xu-Welliver M, Bailey J, D’Souza M, Cooper R, Chandra S, Seshadri R, Pegg AE, Williams DA. Direct reversal of DNA damage by mutant methyltransferase protein protects mice against dose-intensified chemotherapy and leads to in vivo selection of hematopoietic stem cells. Cancer Res 2000;60:5187-5195. [PubMed: 11016647]

[36]. Jansen M, Bardenheuer W, Sorg UR, Seeber S, Flasshove M, Moritz T. Protection of hematopoietic cells from $\mathrm{O}(6)$-alkylation damage by $\mathrm{O}(6)$-methylguanine DNA methyltransferase gene transfer: studies with different O(6)-alkylating agents and retroviral backbones. Eur J Haematol 2001;67:213. [PubMed: 11553261]

[37]. Sawai N, Zhou S, Vanin EF, Houghton P, Brent TP, Sorrentino BP. Protection and in vivo selection of hematopoietic stem cells using temozolomide, O6-benzylguanine, and an alkyltransferaseexpressing retroviral vector. Mol Ther 2001;3:78-87. [PubMed: 11162314]

[38]. Jansen M, Sorg UR, Ragg S, Flasshove M, Seeber S, Williams DA, Moritz T. Hematoprotection and enrichment of transduced cells in vivo after gene transfer of MGMT(P140K) into hematopoietic stem cells. Cancer Gene Ther 2002;9:737-746. [PubMed: 12189523]

[39]. Neff T, Horn PA, Peterson LJ, Thomasson BM, Thompson J, Williams DA, Schmidt M, Georges GE, von Kalle C, Kiem HP. Methylguanine methyltransferase-mediated in vivo selection and chemoprotection of allogeneic stem cells in a large-animal model. J Clin Invest 2003;112:15811588. [PubMed: 14617759] 
[40]. Milsom MD, Fairbairn LJ. Protection and selection for gene therapy in the hematopoietic system. J Gene Med 2004;6:133-146. [PubMed: 14978767]

[41]. Pegg AE. Repair of O(6)-alkylguanine by alkyltransferases. Mutat Res 2000;462:83-100. [PubMed: 10767620]

[42]. Hobin DA, Fairbairn LJ. Genetic chemoprotection with mutant O6-alkylguanine-DNAalkyltransferases. Curr Gene Ther 2002;2:1-8. [PubMed: 12108970]

[43]. McElhinney RS, McMurry TB, Margison GP. O6-alkylguanine-DNA alkyltransferase inactivation in cancer chemotherapy. Mini Rev Med Chem 2003;3:471-485. [PubMed: 12769698]

[44]. Gerson SL. MGMT: its role in cancer aetiology and cancer therapeutics. Nat Rev Cancer 2004;4:296-307. [PubMed: 15057289]

[45]. Mitchell RB, Moschel R, Dolan ME. Effect of O6-benzylguanine on the sensitivity of human tumor xenografts to 1,3-Bis (2-chloroethyl)-1-nitrosourea and on DNA interstrand cross-link formation. Cancer Res 1992;52:1171-1175. [PubMed: 1737376]

[46]. Baer JC, Freeman AA, Newlands ES, Watson AJ, Rafferty JA, Margison GP. Depletion of O6alkylguanine-DNA alkyltransferase correlates with potentiation of temozolomide and CCNU toxicity in human tumor cells. Br J Cancer 1993;67:1299. [PubMed: 8512814]

[47]. Magull-Seltenreich A, Zeller WJ. Sensitization of human colon tumour cell lines to carmustine by depletion of $\mathrm{O}^{6}$-alkylguanine-DNA alkyltransferase. J Cancer Res Clin Oncol 1995;121:225-229. [PubMed: 7751321]

[48]. Dolan ME, Mitchell RB, Mummert C, Moschel RC, Pegg AE. Effect of O6-benzylguanine analogues on sensitivity of human tumor cells to the cytotoxic effects of alkylating agents. Cancer Research 1991;51:3367-3372. [PubMed: 1647266]

[49]. Clemons M, Kelly J, Watson AJ, Howell A, McElhinney RS, McMurry TB, Margison GP. O6-(4bromothenyl)guanine reverses temozolomide resistance in human breast tumour MCF-7 cells and xenografts. Br J Cancer 2005;93:1152-1156. [PubMed: 16278661]

[50]. Quinn JA, Pluda J, Dolan ME, Delaney S, Kaplan R, Rich JN, Friedman AH, Reardon DA, Sampson JH, Colvin OM, Haglund MM, Pegg AE, Moschel RC, McLendon RE, Provenzale JM, Gururangan S, Tourt-Uhlig S, Herndon JE 2nd, Bigner DD, Friedman HS. Phase II trial of carmustine plus O (6)-benzylguanine for patients with nitrosourea-resistant recurrent or progressive malignant glioma. J Clin Oncol 2002;20:2277-2283. [PubMed: 11980998]

[51]. Gerson SL, Phillips W, Kastan M, Dumenco LL, Donovan C. Human CD34+ hematopoietic progenitors have low cytokine-unresponsive O6-alkylguanine-DNA alkyltransferase and are sensitive to O6-benzylguanine plus BCNU. Blood 1996;88:1649-1655. [PubMed: 8781420]

[52]. Fairbairn LJ, Watson AJ, Rafferty JA, Elder RH, Margison GP. O6-benzylguanine increases the sensitivity of human primary bone marrow cells to the cytotoxic effects of temozolomide. Exp Hematol 1995;23:112-116. [PubMed: 7828668]

[53]. Chinnasamy N, Rafferty JA, Hickson I, Ashby J, H T, Margison GP, Dexter TM, Fairbairn LJ. $\mathrm{O}^{6}$-benzylguanine potentiates the in vivo toxicity and clastogenicity of temozolomide and BCNU in mouse bone marrow. Blood 1997;89:1566-1573. [PubMed: 9057638]

[54]. Ryan CW, Dolan ME, Brockstein BB, McLendon R, Delaney SM, Samuels BL, Agamah ES, Vokes EE. A phase II trial of $\mathrm{O}$ (6)-benzylguanine and carmustine in patients with advanced soft tissue sarcoma. Cancer Chemother Pharmacol. 2006

[55]. Gajewski TF, Sosman J, Gerson SL, Liu L, Dolan E, Lin S, Vokes EE. Phase II trial of the O6alkylguanine DNA alkyltransferase inhibitor O6-benzylguanine and 1,3-bis(2-chloroethyl)-1nitrosourea in advanced melanoma. Clin Cancer Res 2005;11:7861-7865. [PubMed: 16278409]

[56]. Schilsky RL, Dolan ME, Bertucci D, Ewesuedo RB, Vogelzang NJ, Mani S, Wilson LR, Ratain MJ. Phase I clinical and pharmacological study of O6-benzylguanine followed by carmustine in patients with advanced cancer. Clin Cancer Res 2000;6:3025-3031. [PubMed: 10955780]

[57]. Ranson M, Middleton MR, Bridgewater J, Lee SM, Dawson M, Jowle D, Halbert G, Waller S, McGrath H, Gumbrell L, McElhinney RS, Donnelly D, McMurry TB, Margison GP. Lomeguatrib, a potent inhibitor of O6-alkylguanine-DNA-alkyltransferase: phase I safety, pharmacodynamic, and pharmacokinetic trial and evaluation in combination with temozolomide in patients with advanced solid tumors. Clin Cancer Res 2006;12:1577-1584. [PubMed: 16533784] 
[58]. Crone TM, Pegg AE. A single amino acid change in human O6-alkylguanine-DNA alkyltransferase decreasing sensitivity to inactivation by O6-benzylguanine. Cancer Res 1993;53:4750-4753. [PubMed: 8402653]

[59]. Crone TM, Goodtzova K, Edara S, Pegg AE. Mutations in human O6-alkylguanine-DNA alkyltransferase imparting resistance to O6-benzylguanine. Cancer Res 1994;54:6221-6227. [PubMed: 7954470]

[60]. Bowman JE, Reese JS, Lingas KT, Gerson SL. Myeloablation is not required to select and maintain expression of the drug-resistance gene, mutant MGMT, in primary and secondary recipients. Mol Ther 2003;8:42-50. [PubMed: 12842427]

[61]. Kreklau EL, Pollok KE, Bailey BJ, Liu N, Hartwell JR, Williams DA, Erickson LC. Hematopoietic expression of $\mathrm{O}(6)$-methylguanine DNA methyltransferase-P140K allows intensive treatment of human glioma xenografts with combination $\mathrm{O}(6)$-benzylguanine and 1,3-bis-(2-chloroethyl)-1nitrosourea. Mol Cancer Ther 2003;2:1321-1329. [PubMed: 14707273]

[62]. Neff T, Beard BC, Peterson LJ, Anandakumar P, Thompson J, Kiem HP. Polyclonal chemoprotection against temozolomide in a large-animal model of drug resistance gene therapy. Blood 2005;105:997-1002. [PubMed: 15494421]

[63]. Woolford LB, Southgate TD, Margison GP, Milsom MD, Fairbairn LJ. The P140K mutant of human $\mathrm{O}(6)$-methylguanine-DNA-methyltransferase (MGMT) confers resistance in vitro and in vivo to temozolomide in combination with the novel MGMT inactivator $\mathrm{O}(6)$-(4-bromothenyl)guanine. J Gene Med 2006;8:29-34. [PubMed: 16075413]

[64]. Pollok KE, Hartwell JR, Braber A, Cooper RJ, Jansen M, Ragg S, Bailey BJ, Erickson LC, Kreklau EL, Williams DA. In vivo selection of human hematopoietic cells in a xenograft model using combined pharmacologic and genetic manipulations. Hum Gene Ther 2003;14:1703-1714. [PubMed: 14670122]

[65]. Persons DA, Allay ER, Sawai N, Hargrove PW, Brent TP, Hanawa H, Nienhuis AW, Sorrentino BP. Successful treatment of murine beta-thalassemia using in vivo selection of genetically modified, drug-resistant hematopoietic stem cells. Blood 2003;102:506-513. [PubMed: 12663444]

[66]. Richard E, Geronimi F, Lalanne M, Ged C, Redonnet-Vernhet I, Lamrissi-Garcia I, Gerson SL, de Verneuil H, Moreau-Gaudry F. A bicistronic SIN-lentiviral vector containing G156A MGMT allows selection and metabolic correction of hematopoietic protoporphyric cell lines. J Gene Med 2003;5:737-747. [PubMed: 12950064]

[67]. Davis BM, Humeau L, Dropulic B. In vivo selection for human and murine hematopoietic cells transduced with a therapeutic MGMT lentiviral vector that inhibits HIV replication. Mol Ther 2004;9:160-172. [PubMed: 14759800]

[68]. Schambach A, Bohne J, Baum C, Hermann FG, Egerer L, von Laer D, Giroglou T. Woodchuck hepatitis virus post-transcriptional regulatory element deleted from $\mathrm{X}$ protein and promoter sequences enhances retroviral vector titer and expression. Gene Ther 2006;13:641-645. [PubMed: 16355114]

[69]. Reese JS, Lingas K, Ksenich P, Sweeney C, Koc O, Gerson S. Preliminary results of a phase I trial using retroviral gene transfer of G156A MGMT to protect hematopoiesis during BG and BCNU therapy of advanced malignancies. Molecular Therapy 2004;9:S385.

[70]. Cornetta K, Croop J, Dropcho E, Abonour R, Kieran MW, Kreissman S, Reeves L, Erickson LC, Williams DA. A pilot study of dose-intensified procarbazine, CCNU, vincristine for poor prognosis brain tumors utilizing fibronectin-assisted, retroviral-mediated modification of CD34+ peripheral blood cells with O6-methylguanine DNA methyltransferase. Cancer Gene Ther. 2006

[71]. de Felipe P. Polycistronic viral vectors. Curr Gene Ther 2002;2:355-378. [PubMed: 12189721]

[72]. Chinnasamy D, Milsom MD, Shaffer J, Neuenfeldt J, Shaaban AF, Margison GP, Fairbairn LJ, Chinnasamy N. Multicistronic lentiviral vectors containing the FMDV 2A cleavage factor demonstrate robust expression of encoded genes at limiting MOI. Virol J 2006;3:14. [PubMed: 16539700]

[73]. Bodine, DM. Hematopoietic Stem Cell Therapy: Progress and Prospects. In: Zon, LI., editor. Hematopoiesis A Developmental Approach. Oxford University PRess; 2001. p. 130-146. 
[74]. Kaina B, Ochs K, Grosch S, Fritz G, Lips J, Tomicic M, Dunkern T, Christmann M. BER, MGMT, and MMR in defense against alkylation-induced genotoxicity and apoptosis. Prog Nucleic Acid Res Mol Biol 2001;68:41-54. [PubMed: 11554312]

[75]. Debiak M, Nikolova T, Kaina B. Loss of ATM sensitizes against O6-methylguanine triggered apoptosis, SCEs and chromosomal aberrations. DNA Repair (Amst) 2004;3:359-368. [PubMed: 15010311]

[76]. Roos WP, Batista LF, Naumann SC, Wick W, Weller M, Menck CF, Kaina B. Apoptosis in malignant glioma cells triggered by the temozolomide-induced DNA lesion $\mathrm{O}(6)$-methylguanine. Oncogene. 2006

[77]. Sanada M, Takagi Y, Ito R, Sekiguchi M. Killing and mutagenic actions of dacarbazine, a chemotherapeutic alkylating agent, on human and mouse cells: effects of Mgmt and Mlh1 mutations. DNA Repair (Amst) 2004;3:413-420. [PubMed: 15010317]

[78]. Hong MY, Chapkin RS, Wild CP, Morris JS, Wang N, Carroll RJ, Turner ND, Lupton JR. Relationship between DNA adduct levels, repair enzyme, and apoptosis as a function of DNA methylation by azoxymethane. Cell Growth Differ 1999;10:749-758. [PubMed: 10593651]

[79]. Margison GP, Santibanez Koref MF, Povey AC. Mechanisms of carcinogenicity/chemotherapy by O6-methylguanine. Mutagenesis 2002;17:483-487. [PubMed: 12435845]

[80]. Kaina B. Mechanisms and consequences of methylating agent-induced SCEs and chromosomal aberrations: a long road traveled and still a far way to go. Cytogenet Genome Res 2004;104:77-86. [PubMed: 15162018]

[81]. Rasouli-Nia A, Sibghat U, Mirzayans R, Paterson MC, Day RS 3rd. On the quantitative relationship between O6-methylguanine residues in genomic DNA and production of sister-chromatid exchanges, mutations and lethal events in a Mer- human tumor cell line. Mutat Res 1994;314:99113. [PubMed: 7510369]

[82]. Chinnasamy N, Fairbairn LJ, Laher J, Willington MA, Rafferty JA. Modulation of O6-alkylating agent induced clastogenicity by enhanced DNA repair capacity of bone marrow cells. Mutat Res 1998;416:1-10. [PubMed: 9725988]

[83]. Fairbairn LJ, Chinnasamy N, Lashford LS, Chinnasamy D, Rafferty JA. Enhancing hemopoietic drug resistance: a rationale for reconsidering the clinical use of mitozolomide. Cancer Gene Ther 2000;7:233-239. [PubMed: 10770631]

[84]. von Hofe E, Fairbairn L, Margison GP. Relationship between O6-alkylguanine-DNA alkyltransferase activity and N-methyl-N'-nitro-N-nitrosoguanidine-induced mutation, transformation, and cytotoxicity in $\mathrm{C} 3 \mathrm{H} / 10 \mathrm{~T} 1 / 2$ cells expressing exogenous alkyltransferase genes. Proc Natl Acad Sci U S A 1992;89:11199-11203. [PubMed: 1454799]

[85]. Dumenco LL, Allay E, Norton K, Gerson SL. The prevention of thymic lymphomas in transgenic mice by human O6-alkylguanine-DNA alkyltransferase. Science 1993;259:219-222. [PubMed: 8421782]

[86]. Liu L, Allay E, Dumenco LL, Gerson SL. Rapid repair of O6-methylguanine-DNA adducts protects transgenic mice from N-methylnitrosourea-induced thymic lymphomas. Cancer Res 1994;54:46484652. [PubMed: 8062258]

[87]. Liu L, Qin X, Gerson SL. Reduced lung tumorigenesis in human methylguanine DNA-methyltransferase transgenic mice achieved by expression of transgene within the target cell. Carcinogenesis 1999;20:279-284. [PubMed: 10069465]

[88]. Allay E, Reese JS, McGuire EA, Koc ON, Sedransk N, Gerson SL. Potentiation of lymphomagenesis by methylnitrosourea in mice transgenic for LMO1 is blocked by O6-alkylguanine DNAalkyltransferase. Oncogene 1997;15:2127-2132. [PubMed: 9366529]

[89]. Reese JS, Allay E, Gerson SL. Overexpression of human O6-alkylguanine DNA alkyltransferase (AGT) prevents MNU induced lymphomas in heterozygous p53 deficient mice. Oncogene 2001;20:5258-5263. [PubMed: 11536039]

[90]. Davis BM, Reese JS, Koc ON, Lee K, Schupp JE, Gerson SL. Selection for G156A O6methylguanine DNA methyltransferase gene- transduced hematopoietic progenitors and protection from lethality in mice treated with O6-benzylguanine and 1,3-bis(2-chloroethyl)-1-nitrosourea. Cancer Research 1997;57:5093-5099. [PubMed: 9371508] 
[91]. Warren KE, Aikin AA, Libucha M, Widemann BC, Fox E, Packer RJ, Balis FM. Phase I study of O6-benzylguanine and temozolomide administered daily for 5 days to pediatric patients with solid tumors. J Clin Oncol 2005;23:7646-7653. [PubMed: 16234526]

[92]. Quinn JA, Desjardins A, Weingart J, Brem H, Dolan ME, Delaney SM, Vredenburgh J, Rich J, Friedman AH, Reardon DA, Sampson JH, Pegg AE, Moschel RC, Birch R, McLendon RE, Provenzale JM, Gururangan S, Dancey JE, Maxwell J, Tourt-Uhlig S, Herndon JE 2nd, Bigner DD, Friedman HS. Phase I trial of temozolomide plus O6-benzylguanine for patients with recurrent or progressive malignant glioma. J Clin Oncol 2005;23:7178-7187. [PubMed: 16192602]

[93]. Maher VM, Domoradzki J, Bhattacharyya NP, Tsujimura T, Corner RC, McCormick JJ. Alkylation damage, DNA repair and mutagenesis in human cells. Mutat Res 1990;233:235-245. [PubMed: 2233805]

[94]. Sukumar S, Barbacid M. Specific patterns of oncogene activation in transplacentally induced tumors. Proc Natl Acad Sci U S A 1990;87:718-722. [PubMed: 2405388]

[95]. Vogel EW, Nivard MJ, Ballering LA, Bartsch H, Barbin A, Nair J, Comendador MA, Sierra LM, Aguirrezabalaga I, Tosal L, Ehrenberg L, Fuchs RP, Janel-Bintz R, Maenhaut-Michel G, Montesano R, Hall J, Kang H, Miele M, Thomale J, Bender K, Engelbergs J, Rajewsky MF. DNA damage and repair in mutagenesis and carcinogenesis: implications of structure-activity relationships for crossspecies extrapolation. Mutat Res 1996;353:177-218. [PubMed: 8692191]

[96]. Baum C, Duellman J, Li Z, Fehse B, Meyer J, Williams DA, von Kalle C. Side effects of retroviral gene transfer into hematopoietic stem cells. Blood 2003;101:2099-2114. [PubMed: 12511419]

[97]. Williams DA, Baum C. Medicine. Gene therapy--new challenges ahead. Science 2003;302:400401. [PubMed: 14563994]

[98]. von Kalle C, Fehse B, Layh-Schmitt G, Schmidt M, Kelly P, Baum C. Stem cell clonality and genotoxicity in hematopoietic cells: gene activation side effects should be avoidable. Semin Hematol 2004;41:303-318. [PubMed: 15508116]

[99]. Baum C, von Kalle C, Staal FJ, Li Z, Fehse B, Schmidt M, Weerkamp F, Karlsson S, Wagemaker $\mathrm{G}$, Williams DA. Chance or necessity? Insertional mutagenesis in gene therapy and its consequences. Mol Ther 2004;9:5-13. [PubMed: 14741772]

[100]. Ferguson C, Larochelle A, Dunbar CE. Hematopoietic stem cell gene therapy: dead or alive? Trends Biotechnol 2005;23:589-597. [PubMed: 16216357]

[101]. Baum C, Kustikova O, Modlich U, Li Z, Fehse B. Mutagenesis and oncogenesis by chromosomal insertion of gene transfer vectors. Hum Gene Ther 2006;17:253-263. [PubMed: 16544975]

[102]. Kohn DB, Sadelain M, Dunbar C, Bodine D, Kiem HP, Candotti F, Tisdale J, Riviere I, Blau CA, Richard RE, Sorrentino B, Nolta J, Malech H, Brenner M, Cornetta K, Cavagnaro J, High K, Glorioso J. American Society of Gene Therapy (ASGT) ad hoc subcommittee on retroviralmediated gene transfer to hematopoietic stem cells. Mol Ther 2003;8:180-187. [PubMed: 12907140]

[103]. Modlich U, Kustikova OS, Schmidt M, Rudolph C, Meyer J, Li Z, Kamino K, von Neuhoff N, Schlegelberger B, Kuehlcke K, Bunting KD, Schmidt S, Deichmann A, von Kalle C, Fehse B, Baum C. Leukemias following retroviral transfer of multidrug resistance 1 (MDR1) are driven by combinatorial insertional mutagenesis. Blood 2005;105:4235-4246. [PubMed: 15713797]

[104]. Li Z, Dullmann J, Schiedlmeier B, Schmidt M, von Kalle C, Meyer J, Forster M, Stocking C, Wahlers A, Frank O, Ostertag W, Kuhlcke K, Eckert HG, Fehse B, Baum C. Murine leukemia induced by retroviral gene marking. Science 2002;296:497. [PubMed: 11964471]

[105]. Suzuki T, Minehata K, Akagi K, Jenkins NA, Copeland NG. Tumor suppressor gene identification using retroviral insertional mutagenesis in Blm-deficient mice. Embo J 2006;25:3422-3431. [PubMed: 16858412]

[106]. De Palma M, Montini E, de Sio FR, Benedicenti F, Gentile A, Medico E, Naldini L. Promoter trapping reveals significant differences in integration site selection between MLV and HIV vectors in primary hematopoietic cells. Blood 2005;105:2307-2315. [PubMed: 15542582]

[107]. Laufs S, Nagy KZ, Giordano FA, Hotz-Wagenblatt A, Zeller WJ, Fruehauf S. Insertion of retroviral vectors in NOD/SCID repopulating human peripheral blood progenitor cells occurs preferentially in the vicinity of transcription start regions and in introns. Mol Ther 2004;10:874-881. [PubMed: 15509505] 
[108]. Trobridge GD, Miller DG, Jacobs MA, Allen JM, Kiem HP, Kaul R, Russell DW. Foamy virus vector integration sites in normal human cells. Proc Natl Acad Sci U S A 2006;103:1498-1503. [PubMed: 16428288]

[109]. Dunbar CE. Stem cell gene transfer: insights into integration and hematopoiesis from primate genetic marking studies. Ann N Y Acad Sci 2005;1044:178-182. [PubMed: 15958711]

[110]. Nowrouzi A, Dittrich M, Klanke C, Heinkelein M, Rammling M, Dandekar T, von Kalle C, Rethwilm A. Genome-wide mapping of foamy virus vector integrations into a human cell line. $\mathrm{J}$ Gen Virol 2006;87:1339-1347. [PubMed: 16603537]

[111]. Hematti P, Hong BK, Ferguson C, Adler R, Hanawa H, Sellers S, Holt IE, Eckfeldt CE, Sharma Y, Schmidt M, von Kalle C, Persons DA, Billings EM, Verfaillie CM, Nienhuis AW, Wolfsberg TG, Dunbar CE, Calmels B. Distinct genomic integration of MLV and SIV vectors in primate hematopoietic stem and progenitor cells. PLoS Biol 2004;2:e423. [PubMed: 15550989]

[112]. Montini E, Cesana D, Schmidt M, Sanvito F, Ponzoni M, Bartholomae C, Sergi LS, Benedicenti F, Ambrosi A, Di Serio C, Doglioni C, von Kalle C, Naldini L. Hematopoietic stem cell gene transfer in a tumor-prone mouse model uncovers low genotoxicity of lentiviral vector integration. Nat Biotechnol 2006;24:687-696. [PubMed: 16732270]

[113]. Modlich U, Bohne J, Schmidt M, von Kalle C, Knob S, Schambach A, Baum C. Cell culture assays reveal the importance of retroviral vector design for insertional genotoxicity. Blood. 2006

[114]. Woods NB, Bottero V, Schmidt M, von Kalle C, M I. Verma Gene therapy: therapeutic gene causing lymphoma. Nature 2006;440:1123. [PubMed: 16641981]

[115]. A D. Williams Gene therapy advances but struggles to interpret safety data in small animal models. Mol Ther 2006;13:1027-1028. [PubMed: 16684622]

[116].

ThrasherAJGasparBBaumCModlichUSchambachACandottiFOtsuMSorrentinoBScobieLCamero nEBlythKNeilJHacein-Bey-AbinaSCavazzana-CalvoMFisherALack of transgene leukaemogenicity. Nature In Press 2006

[117]. Gaspar HB, Parsley KL, Howe S, King D, Gilmour KC, Sinclair J, Brouns G, Schmidt M, Von Kalle C, Barington T, Jakobsen MA, Christensen HO, Al Ghonaium A, White HN, Smith JL, Levinsky RJ, Ali RR, Kinnon C, Thrasher AJ. Gene therapy of X-linked severe combined immunodeficiency by use of a pseudotyped gammaretroviral vector. Lancet 2004;364:2181-2187. [PubMed: 15610804]

[118]. Richard E, Robert E, Cario-Andre M, Ged C, Geronimi F, Gerson SL, de Verneuil H, MoreauGaudry F. Hematopoietic stem cell gene therapy of murine protoporphyria by methylguanine-DNAmethyltransferase-mediated in vivo drug selection. Gene Ther 2004;11:1638-1647. [PubMed: 15284838]

[119]. Zielske S, Lingas KT, Li Y, Gerson SL. Limited Lentiviral Transgene Expression with Increasing Copy Number in an MGMT Selection Model: Lack of Copy Number Selection by Drug Treatment. Molecular Therapy 2004;9:923-931. [PubMed: 15194059]

[120]. Seggewiss R, Pittaluga S, Adler RL, Guenaga FJ, Ferguson C, Pilz IH, Ryu B, Sorrentino BP, Young WS 3rd, Donahue RE, von Kalle C, Nienhuis AW, Dunbar CE. Acute myeloid leukemia is associated with retroviral gene transfer to hematopoietic progenitor cells in a rhesus macaque. Blood 2006;107:3865-3867. [PubMed: 16439674]

[121]. Botnick LE, Hannon EC, Hellman S. A long lasting proliferative defect in the hematopoietic stem cell compartment following cytotoxic agents. Int J Radiat Oncol Biol Phys 1979;5:1621-1625. [PubMed: 395140]

[122]. Sawai N, Persons DA, Zhou S, Lu T, Sorrentino BP. Reduction in hematopoietic stem cell numbers with in vivo drug selection can be partially abrogated by HOXB4 gene expression. Mol Ther 2003;8:376-384. [PubMed: 12946310]

[123]. Cai S, Hartwell JR, Cooper RJ, Juliar BE, Kreklau E, Abonour R, Goebel WS, Pollok KE. In vivo effects of myeloablative alkylator therapy on survival and differentiation of MGMTP140Ktransduced human G-CSF-mobilized peripheral blood cells. Mol Ther 2006;13:1016-1026. [PubMed: 16426896] 
[124]. Zielske SP, Reese JS, Lingas KT, Donze JR, Gerson SL. In vivo selection of MGMT(P140K) lentivirus-transduced human NOD/SCID repopulating cells without pretransplant irradiation conditioning. J Clin Invest 2003;112:1561-1570. [PubMed: 14617757]

[125]. Baum C, Schambach A, Bohne J, Galla M. Retrovirus vectors: toward the plentivirus? Mol Ther 2006;13:1050-1063. [PubMed: 16632409]

[126]. Schambach A, Bohne J, Chandra S, Will E, Margison GP, Williams DA, Baum C. Equal potency of gammaretroviral and lentiviral SIN vectors for expression of O6-methylguanine-DNA methyltransferase in hematopoietic cells. Mol Ther 2006;13:391-400. [PubMed: 16226060]

[127]. Kaina B, Fritz G, Mitra S, Coquerelle T. Transfection and expression of human O6-methylguanineDNA methyltransferase (MGMT) cDNA in Chinese hamster cells: the role of MGMT in protection against the genotoxic effects of alkylating agents. Carcinogenesis 1991;12:1857-1867. [PubMed: 1657427]

[128]. SchambachABaumCMGMT retroviral expression systems. DNA Repair In Press 2006 


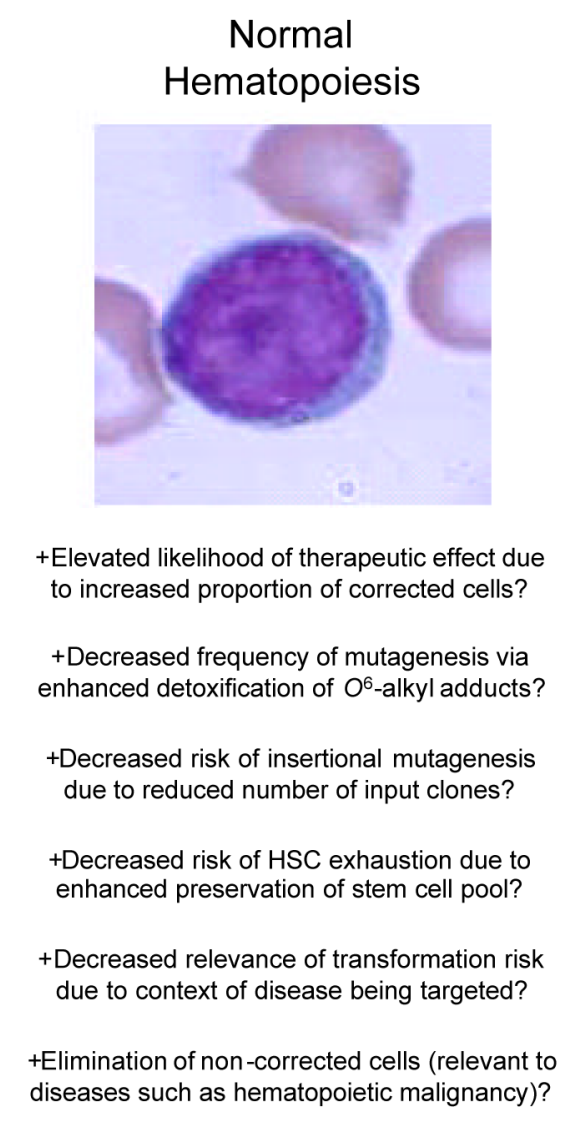

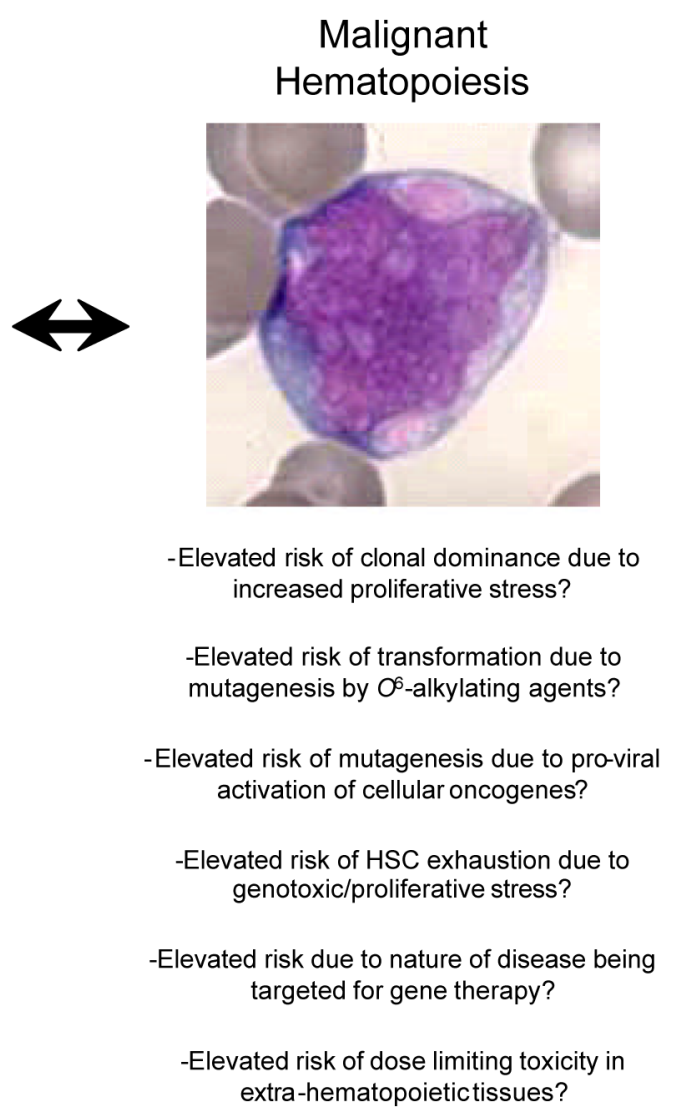

\section{Malignant}

Figure 1.

Schematic depiction of the perceived risk and benefits relating to MGMT chemoselection of retroviral transduced HSC. These factors need to be carefully weighed against each other, using the available pre-clinical and clinical data, in order to determine whether this approach is applicable to any particular disease application. The interplay of these issues may result in an adverse outcome (malignancy) or a favorable outcome (normal "gene-corrected" hematopoiesis). Images used with permission from BloodLine (www.bloodline.net). Copyright 2006 Carden Jennings Publishing Co., Ltd. All rights reserved. 